\title{
※USGS
}

science for a changing world

Studies by the U.S. Geological Survey in Alaska, 2007

\section{The January 2006 Volcanic-Tectonic Earthquake Swarm at Mount Martin, Alaska}

Professional Paper 1760-D

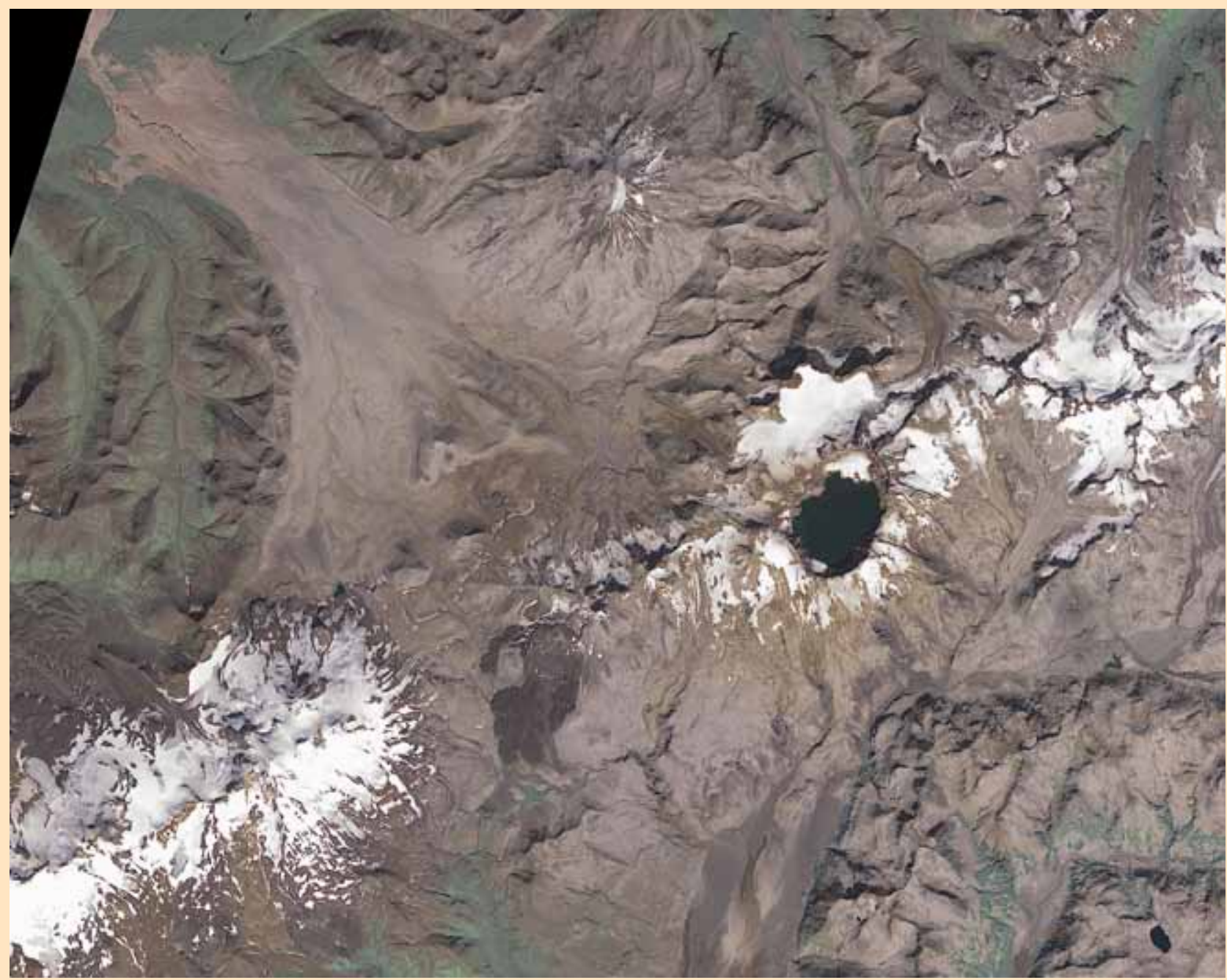

U.S. Department of the Interior U.S. Geological Survey 
This page intentionally left blank 
Studies by the U.S. Geological Survey in Alaska, 2007

\section{The January 2006 Volcanic-Tectonic Earthquake Swarm at Mount Martin, Alaska}

By James P. Dixon and John A. Power

Professional Paper 1760-D

U.S. Department of the Interior

U.S. Geological Survey 


\title{
U.S. Department of the Interior KEN SALAZAR, Secretary
}

\author{
U.S. Geological Survey \\ Suzette M. Kimball, Acting Director
}

U.S. Geological Survey, Reston, Virginia: 2009

This report and any updates to it are available online at:

http://pubs.usgs.gov/pp/1760/d/

For more information about the USGS and its products:

Telephone: 1-888-ASK-USGS (1-888-275-8747)

World Wide Web: http://www.usgs.gov/

Any use of trade, product, or firm names in this publication is for descriptive purposes only and does not imply endorsement by the U.S. Government.

Although this report is in the public domain, it may contain copyrighted materials that are noted in the text. Permission to reproduce those items must be secured from the individual copyright owners.

Produced in the Western Region, Menlo Park, California

Manuscript approved for publication, July 14, 2009

Text edited by Tracey Suzuki

Layout and design by Stephen L. Scott

Suggested citation:

Dixon, J.P., and Power, J.A., 2009, The January 2006 volcanic-tectonic earthquake swarm at Mount Martin, Alaska, in Haeussler, P.J., and Galloway, J.P., eds., Studies by the U.S. Geological Survey in Alaska, 2007: U.S. Geological Survey Professional Paper 1760-D, 17 p.

FRONT COVER

Landsat image of Katmai National Park, Alaska, August 16, 2000. 


\section{Contents}

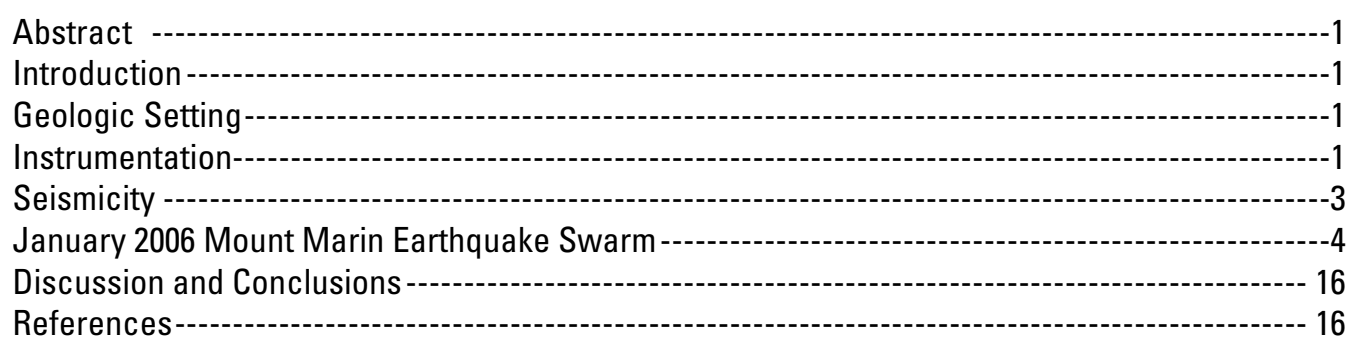

\section{Figures}

1. Landsat 7 image of Katmai National Park, Alaska August 16, 2000 -----

2. Seismograph network for the Katmai volcanic cluster ---

3. Map and cross section of earthquakes located in the Katmai volcanic cluster

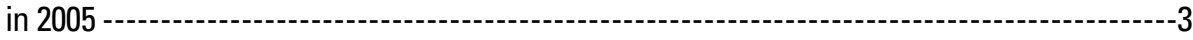

4. Number of earthquakes located per month since 1996 within $5 \mathrm{~km}$ of

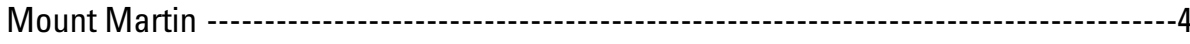

5. Epicenter maps, cross sections, time history, and magnitude distributions for the periods of increased earthquake activity at Mount Martin -------------------5

6. Map view of earthquake locations in the Alaska Volcano Observatory catalog-----------6

7. Earthquake epicenters near Mount Martin and Mount Mageik ----------------------7

8. Cross section of earthquake hypocenters in the Katmai volcanic cluster-----------------7

9. Map and cross sections showing the January 2006 Mount Martin

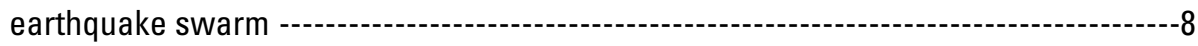

10. Summary plots of earthquake hypocenters of the January 2008 Mount

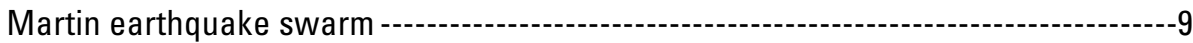

11. A 4-day velocity seismic record from 1800 UTC, January 7, 2006, through 1800 UTC, January 11, 2006, that shows the onset of the Mount Martin earthquake swarm ---------------------2200 UTC, January 16, 2006, that shows the short-term increase in activity on January 14, for the Mount Martin earthquake swarm

13. A 4-day velocity seismic record from 0000 UTC, January 18,2006 , through 2400 UTC January 21, 2006, that shows the seismicity at the end of the Mount Martin earthquake swarm ---------- 12

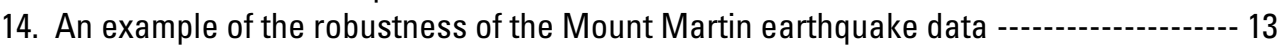

15. The frequency-magnitude distribution ( $b$-value diagram) for the January 2006 Mount Martin earthquake swarm ---:--- 13

16. Focal mechanisms for the Mount Martin earthquake swarm within the main cluster

17. Focal mechanisms for the Mount Martin earthquake swarm outside the main cluster-

\section{Table}

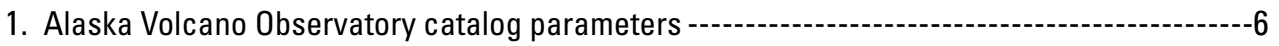


This page intentionally left blank 


\title{
The January 2006 Volcanic-Tectonic Earthquake Swarm at Mount Martin, Alaska
}

\author{
By James P. Dixon and John A. Power
}

\section{Abstract}

On January 8, 2006, a swarm of volcanic-tectonic earthquakes began beneath Mount Martin at the southern end of the Katmai volcanic cluster. This was the first recorded swarm at Mount Martin since continuous seismic monitoring began in 1996. The number of located earthquakes increased during the next four days, reaching a peak on January 11. For the next two days, the seismic activity decreased, and on January 14, the number of events increased to twice the previous day's total. Following this increase in activity, seismicity declined, returning to background levels by the end of the month. The Alaska Volcano Observatory located 860 earthquakes near Mount Martin during January 2006. No additional signs of volcanic unrest were noted in association with this earthquake swarm.

The earthquakes in the Mount Martin swarm, relocated using the double difference technique, formed an elongated cluster dipping to the southwest. Focal mechanisms beneath Mount Martin show a mix of normal, thrust, and strike-slip solutions, with normal focal mechanisms dominating. For earthquakes more than $1 \mathrm{~km}$ from Mount Martin, all focal mechanisms showed normal faulting. The calculated $b$-value for the Mount Martin swarm is 0.98 and showed no significant change before, during, or after the swarm.

The triggering mechanism for the Mount Martin swarm is unknown. The time-history of earthquake occurrence is indicative of a volcanic cause; however, there were no lowfrequency events or observations, such as increased steaming associated with the swarm. During the swarm, there was no change in the b-value, and the distribution and type of focal mechanisms were similar to those in the period before the anomalous activity. The short duration of the swarm, the similarity in observed focal mechanisms, and the lack of additional signs of unrest suggest this swarm did not result from a large influx of magma within the shallow crust beneath Mount Martin.

\section{Introduction}

This study presents a description of the Mount Martin earthquake swarm that occurred in January 2006 at the southern end of the Katmai volcanic cluster (KVC) on the Alaska Peninsula, a N65 ${ }^{\circ}$-trending cluster of volcanoes active in the Holocene (fig. 1). We present background information on the geologic setting of Mount Martin and descriptions of the instrumentation in the KVC and of the seismicity that has occurred near Mount Martin since 1996. Along with a description of the earthquake swarm, we present a comparison of $b$-values from before and after the swarm and focal mechanisms of the larger earthquakes in the 2006 sequence. We conclude that, although the time-history of the earthquake occurrence is indicative of a volcanic cause, there is no evidence from our analyses that this swarm was caused by an influx of magma within the shallow crust.

\section{Geologic Setting}

Mount Martin is the youngest stratocone in the KVC, the successor to Alagogshak volcano, $3 \mathrm{~km}$ to the southwest (Fierstein and Hildreth, 2001). Mount Martin is located near the center of a ridge of altered basement rocks that extends for more than $12 \mathrm{~km}$, west-southwest from Mount Mageik. Mount Martin's summit cone and the adjacent Angle Creek lava-flow field are entirely of Holocene age (Riehle and others, 1987). Historical volcanic activity at Mount Martin has been limited to vigorous fumerolic activity at the summit that continues at the present, unchanged since Mount Martin was first photographed during the 1913-17 Griggs expedition (Fierstein and Hildreth, 2001).

\section{Instrumentation}

Before the installation of a permanent seismograph network in 1995 to provide for the real-time monitoring of an active and potentially hazardous volcanic area, there were several temporary seismograph networks in the area of the KVC (Decker, R.W., unpub. data, 1963; Matumoto and Ward, 1967; Matumoto, 1971; Pulpan and Kienle, 1979; Ward and others, 1991). These temporary deployments were used to investigate the seismic risk in the eastern Aleutian Arc and the seismicity related to volcanism in the KVC. The largest and 


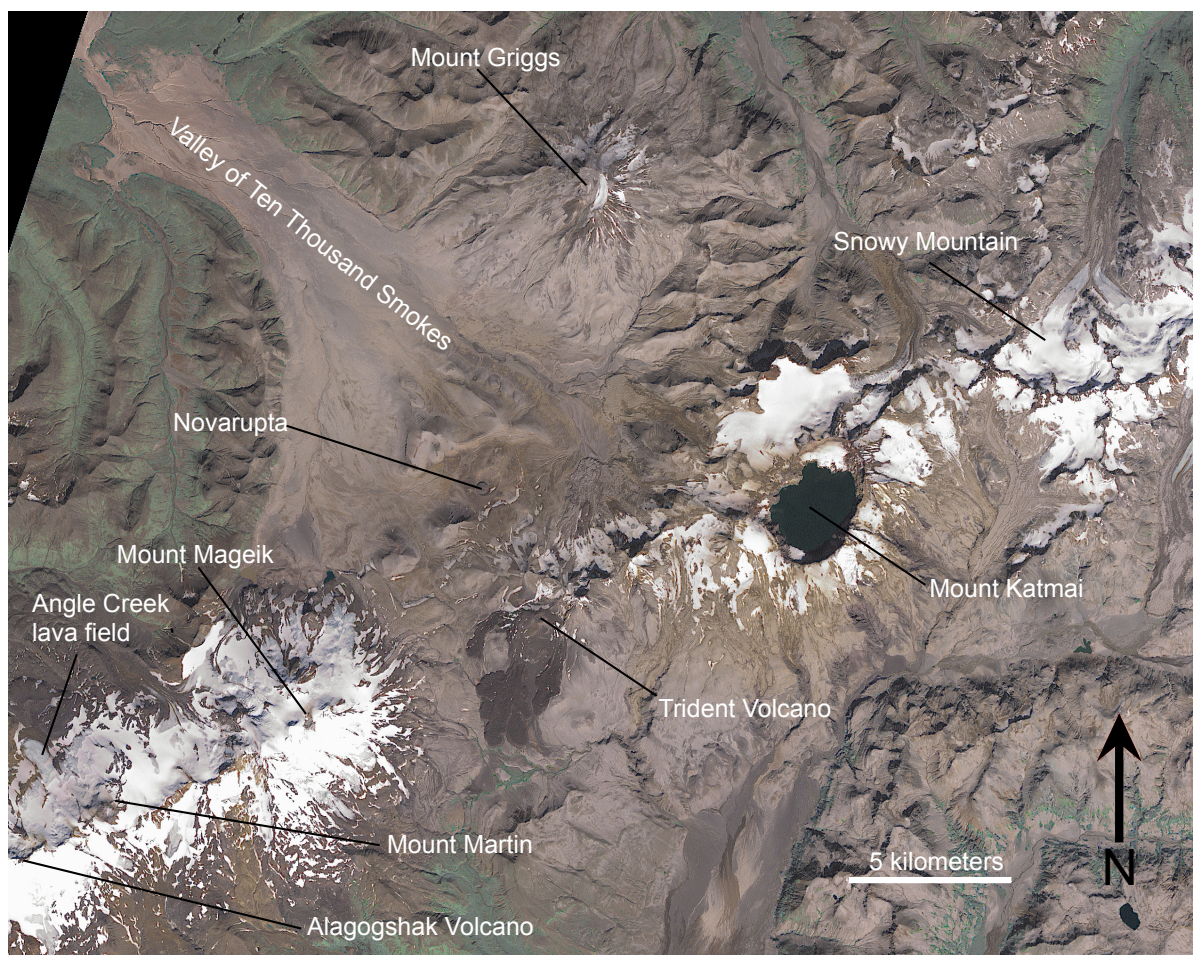

Figure 1. Landsat 7 image of Katmai National Park, Alaska, August 16, 2000. Mount Martin is at the southern end (lower left) of the Katmai volcanic cluster, which also includes Snowy Mountain, Mount Katmai, Mount Griggs, Novarupta, Trident Volcano, and Mount Mageik.

longest continually operating of these temporary networks had 10 to 14 stations in operation between 1987 and 1990 (Ward and others, 1991). A summary of these temporary arrays can be found in Moran (2003).

In 1995, the Alaska Volcano Observatory (AVO) embarked on a three-phase plan to establish a permanent seismograph network in the KVC with data telemetry to a central recording site (fig. 2). In the initial phase, four single-component shortperiod stations and one three-component, short-period station were installed in the central region of the KVC in locations first established by Ward and others (1991). In 1996, a second set of short-period stations, including five single-component stations and one three-component station, were installed at the southern end surrounding the Martin and Mageik volcanic centers. Two years later (in 1998), the network was expanded in the northern part of the KVC. In this last phase of the network installation, eight single-component short-period stations and two three-component, short-period stations were installed. In 2004, two Guralp CMG-6TD broadband stations were added within the central Katmai network as part of an overall initiative to increase the number of broadband stations within the AVO seismic network. All single-component, short-period stations have Mark Products L4 seismometers, and all threecomponent, short-period stations have Mark Products L22 seismometers. Details of the Katmai and other AVO seismograph networks can be found in Dixon and others (2008).

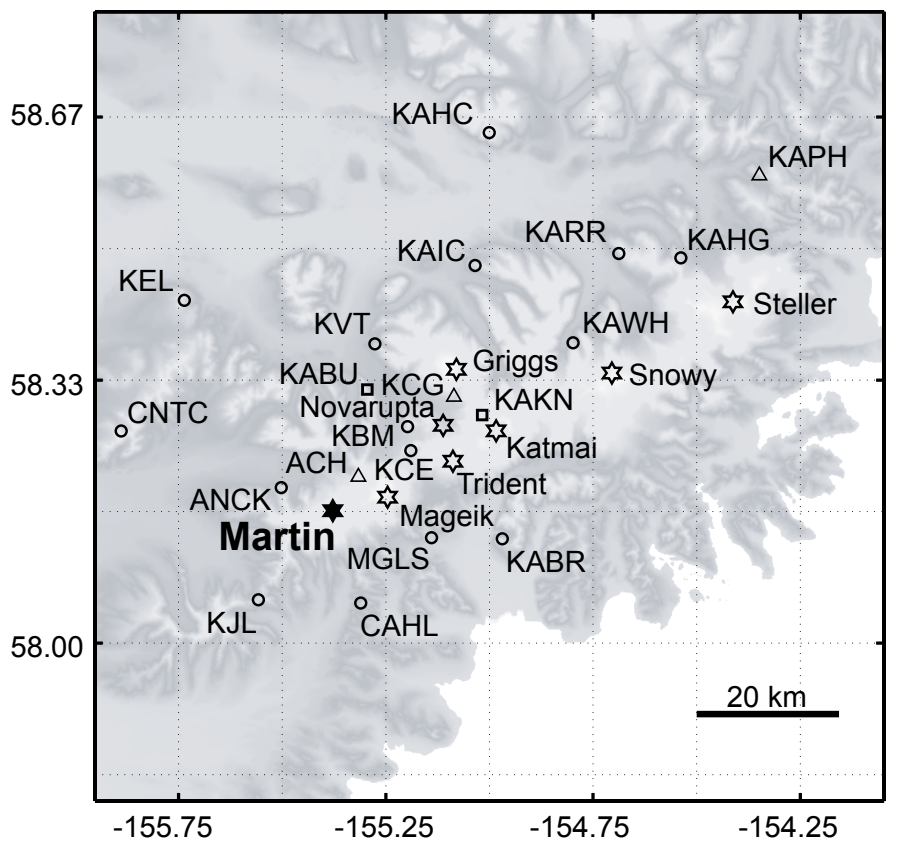

Figure 2. Seismograph network for the Katmai volcanic cluster. Squares show broadband stations; triangles show three-component, short-period stations; and circles show single-component, short-period stations. Stars show the volcanic centers active in the Holocene. Mount Martin is in bold and shown by a filled star. 
The seismograph data were collected and processed using AVO's routine procedures (Dixon and others, 2008). The seismograph data from short-period stations were digitized at 100 samples per second (sps), and broadband stations were digitized at $50 \mathrm{sps}$. Data from short-period stations were telemetered to a communication hub in King Salmon, Alaska by using FM radios. Data from broadband stations were digitized at the station site and digitally transmitted using spreadspectrum radios to the communication hub in King Salmon. Using leased telephone circuits these data were forwarded from King Salmon to AVO offices in Fairbanks and Anchorage for processing. The routine earthquake processing at AVO includes automatically creating individual data files for each earthquake, timing arrivals with an in-house picking program, and locating the earthquakes with HYPOELLIPSE (Lahr, 1999) using a regional velocity model (Searcy, 2003). All earthquakes are located using the NAD27 datum, and depths are presented with respect to average mean sea level (negative depths reflect the height above average mean sea level).

In March 2002 the data-acquisition system was changed from an IASPEI (International Association of Seismology and Physics of the Earth's Interior) acquisition system (Lee and others, 1988) to an Earthworm system (Johnson and others, 1995). The change in data-acquisition systems resulted in an increase in the earthquake-detection rate (Dixon and others 2005), and unless noted, background seismicity rates are from the period starting in March 2002 through the present.

\section{Seismicity}

Four clusters of seismicity have been identified in the KVC at Mount Martin/Mount Mageik, Mount Katmai, Katmai Pass/Trident Volcano and Snowy Mountain (fig. 3;
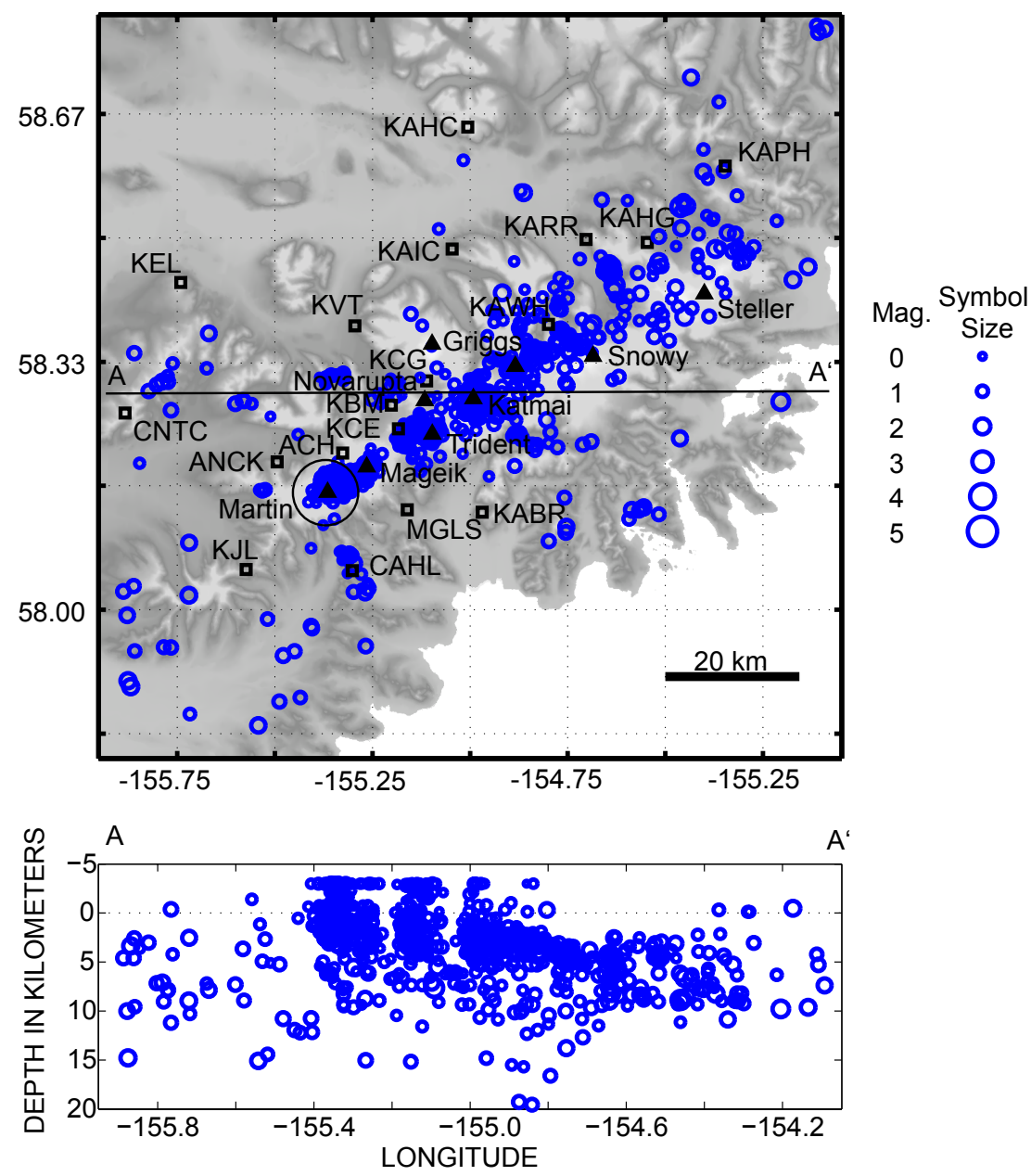

Figure 3. Map and cross section of earthquakes located in the Katmai volcanic cluster in 2005. The distribution of hypocenters is representative of the seismicity recorded since 1996. Open circles show hypocenter locations shallower than $20 \mathrm{~km}$ and open triangles show hypocenters with depths of $20 \mathrm{~km}$ and deeper. Symbols are scaled with magnitude. Permanent seismograph stations are shown by open squares and labeled by station code. Solid triangles are used to show volcanic centers. The circle shows the area within $5 \mathrm{~km}$ of Mount Martin. 
Ward and others, 1991; Jolly and McNutt, 1999; Moran, 2003; Power and others, 2004). The seismicity in the KVC consists predominantly of volcanic-tectonic events and is generally restricted to the upper crust, with less than 14 percent of the located earthquakes occurring at a depth greater than $5 \mathrm{~km}$. In rare instances, deep long-period events have been identified in the KVC (Power and others, 2004).

Since the installation of the AVO Katmai seismograph network in 1995, three significant earthquake swarms have been detected in the KVC. These swarms are (1) the October 1996 Mount Mageik swarm, attributed to active degassing and intrusion (Jolly and McNutt, 1999); (2) an aftershock sequence following a July $14,2002 M_{\mathrm{L}}=3.6$ earthquake near Snowy Mountain; and (3) the January 2006 Mount Martin swarm described in this paper (fig. 4). In the area around Mount Martin, there have been smaller periods of increased earthquake activity in December 1998, May-July 1999, and May-June 2007 (fig. 5).

In all previous seismological studies of the $\mathrm{KVC}$, the earthquake hypocenters at Mount Martin and Mount Mageik were described as a single cluster. In 2000, coincident with the increased stability of the seismic network, it was noted that within the Martin-Mageik cluster there were two distinct clusters at Mount Martin and Mount Mageik (fig. 6). Within the $\mathrm{KVC}$, the earthquakes are densely distributed (earthquake hypocenters are densely distributed if the hypocenters are separated by a few kilometers and located within a seismograph network with stations separated by several tens of kilometers) and the double-difference algorithm of Waldhauser and Ellsworth (2000) works best when earthquakes are densely distributed (Yang and others, 2005). A total of 4,821 earthquakes, composed of 47,156 P-wave phases and 29,191 $\mathrm{S}$-wave phases, were located in the KVC in 2002 through 2005. The double-difference algorithm was used to determine relative earthquake locations within the Martin-Mageik cluster using these earthquakes (figs. 7 and 8). The relocated earthquakes show that the two clusters under Mount Martin and Mount Mageik are distinct. Three smaller clusters were also resolved by HYPODD (Waldhauser, 2001) and are indentified by numbers 3,4 , and 5 in figures 7 and 8 .

\section{January 2006 Mount Martin Earthquake Swarm}

On January 8, 2006, a swarm of 860 volcanic-tectonic earthquakes began beneath Mount Martin, the first significant earthquake swarm at Mount Martin since recording began in the KVC (figs. 9 and 10). The number of located earthquakes continued to increase during the next three days (fig. 11). On January 10, the AVO Level of Concern Color Code (Gardner and Guffanti, 2006) was raised from green to yellow for Mount Martin citing "a marked increase in earthquake activity." The peak activity occurred on January 11, with 174 located earthquakes. The seismic activity decreased during the next two days, with 78 earthquakes on January 12 and 20 earthquakes on January 13. On January 14, the

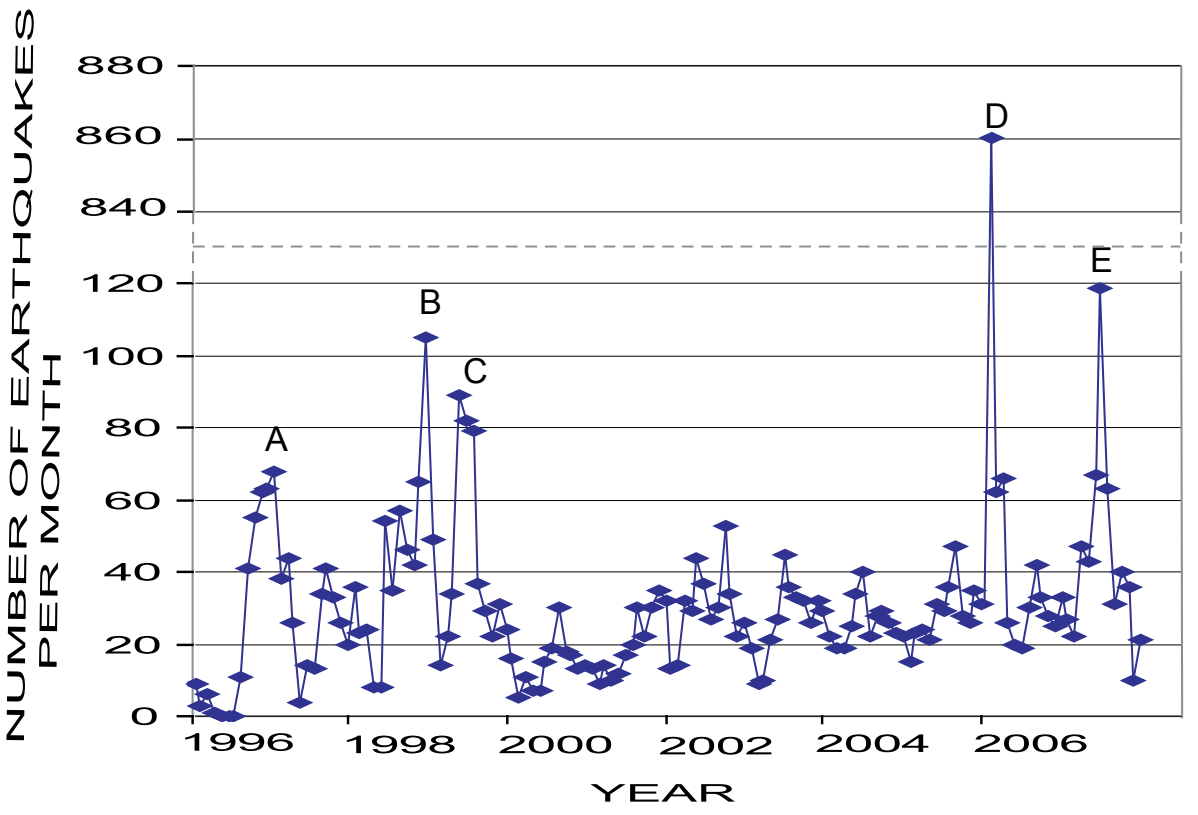

Figure 4. Number of earthquakes located per month since 1996 within $5 \mathrm{~km}$ of Mount Martin. The labeled peaks correspond to (A) part of the nearby October 1996 Mount Mageik earthquake swarm; (B) December 1998 earthquake activity; (C) May-July 1999 earthquake activity; (D) the January 2006 Mount Martin swarm; and (E) May-June 2007 earthquake activity. 

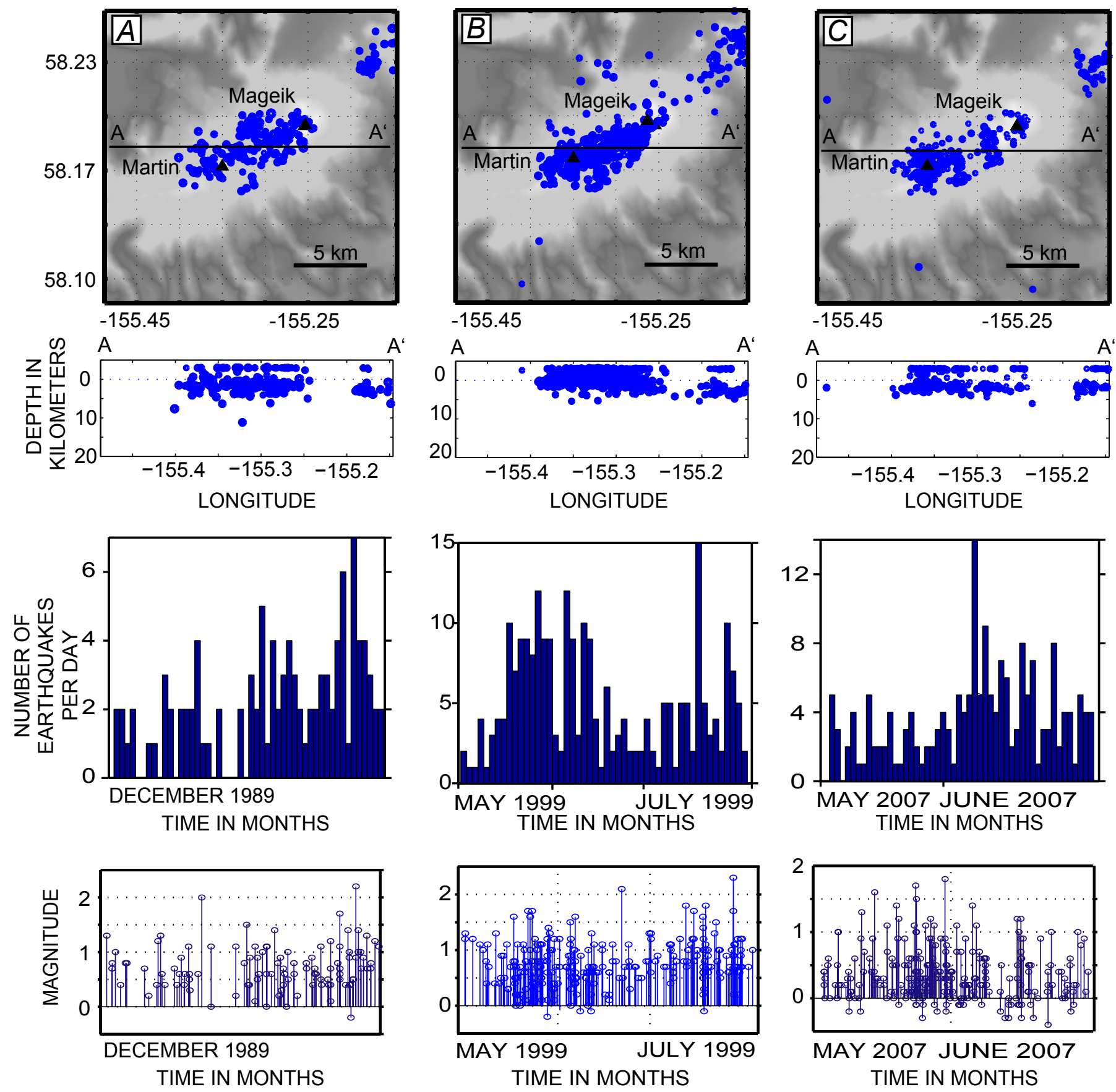

Figure 5. Epicenter maps, cross sections, time history, and magnitude distributions for the periods of increased earthquake activity at Mount Martin in $(A)$ December 1998, $(B)$ May-July 1999, and $(C)$ May-June 2007. Hypocenter locations are shown by dots. Solid triangles are used to show volcanic centers. 
Table 1. Alaska Volcano Observatory catalog parameters for all $M L \geq 1.5$ earthquakes in within $5 \mathrm{~km}$ of Mount Martin in January 2006.

\begin{tabular}{|c|c|c|c|r|c|c|c|c|}
\hline Year & Month & Day & Hr:Min & \multicolumn{1}{c|}{ Sec } & Lat $\left({ }^{\circ} \mathrm{N}\right)$ & Long $\left({ }^{\circ} \mathrm{W}\right)$ & Depth $(\mathrm{km})$ & $\mathrm{M}_{\mathrm{L}}$ \\
\hline 2006 & 1 & 9 & $01: 10$ & 12.24 & 58.1733 & 155.3518 & 1.1 & 1.5 \\
\hline 2006 & 1 & 10 & $04: 39$ & 7.07 & 58.1692 & 155.3452 & 1.8 & 1.5 \\
\hline 2006 & 1 & 10 & $22: 30$ & 54.61 & 58.1738 & 155.3628 & 1.4 & 1.6 \\
\hline 2006 & 1 & 11 & $00: 32$ & 2.18 & 58.1692 & 155.3553 & 1.7 & 1.7 \\
\hline 2006 & 1 & 11 & $06: 52$ & 14.62 & 58.1718 & 155.3812 & 0.1 & 2.1 \\
\hline 2006 & 1 & 11 & $18: 27$ & 7.71 & 58.1648 & 155.3467 & 1.6 & 2.0 \\
\hline 2006 & 1 & 12 & $16: 04$ & 37.15 & 58.1700 & 155.3270 & 3.6 & 1.8 \\
\hline 2006 & 1 & 15 & $17: 18$ & 8.58 & 58.1737 & 155.3313 & 4.1 & 1.9 \\
\hline
\end{tabular}

number of events spiked to 36 earthquakes (fig. 12). Following this spike in activity, seismicity continued to decline, returning to background levels by the end of the month (fig. 13). The AVO Level of Concern Color Code was changed back to green on January 27 citing the "return to background levels" of seismic activity. No additional signs of volcanic unrest (for example, increased steaming, snow melt, and thermal anomalies) were noted in association with this earthquake swarm by either pilot reports or AVO's twice daily remote-sensing check. There were no gas measurements taken or over-flights of Mount Martin in January 2006.

The largest earthquake in the Mount Martin earthquake swarm was a $M_{\mathrm{L}}=2.1$ earthquake that occurred 0652 UTC on January 11 at a hypocentral depth of $0.1 \mathrm{~km}$ (fig. 9; table 1).
Seven other $M_{\mathrm{L}} \geq 1.5$ earthquakes also occurred in January 2006 within $5 \mathrm{~km}$ of Mount Martin (fig. 10D; table 1). The peak in the larger events $\left(M_{\mathrm{L}} \geq 1.5\right)$ coincided with the peak in overall seismicity, with an equal number of large events before and after the peak. There was no single large mainshock $\left(M_{\mathrm{L}} \geq 3.0\right)$ associated with the January Mount Martin earthquake swarm.

The 860 earthquakes (7,352 P-wave phases and 4,407 S-wave phases) that occurred during the January 2006 swarm were relocated using the double-difference technique with the AVO catalog hypocentral locations and the velocity model (Searcy, 2003) as the initial input to HYPODD. The resultant locations form an elongated cluster that dips to the southwest (fig. 9). The earthquake hypocenters for the Janu-
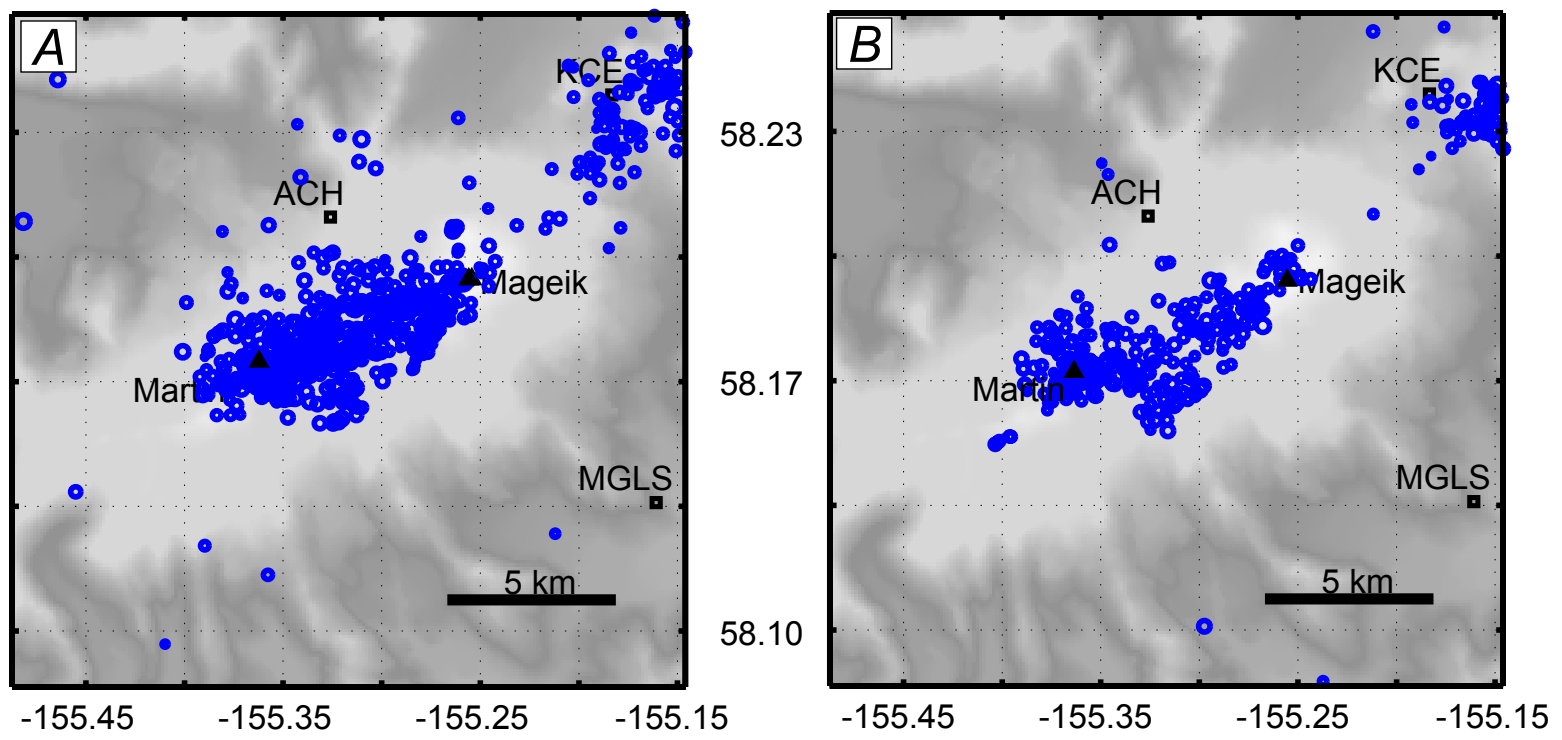

Figure 6. Map view of earthquake locations in the Alaska Volcano Observatory catalog (Dixon and others, 2008) for (A) 1999 and (B) 2001 near Mount Martin. Seismograph stations are shown by open squares and volcanic centers are shown by triangles. Earthquake epicenters are scaled by magnitude and are shown as blue circles. The earthquakes at Mount Martin and Mount Mageik in $A$ appear to be a single cluster of activity,whereas the earthquakes in $B$ appear to have two distinct clusters of activity. 

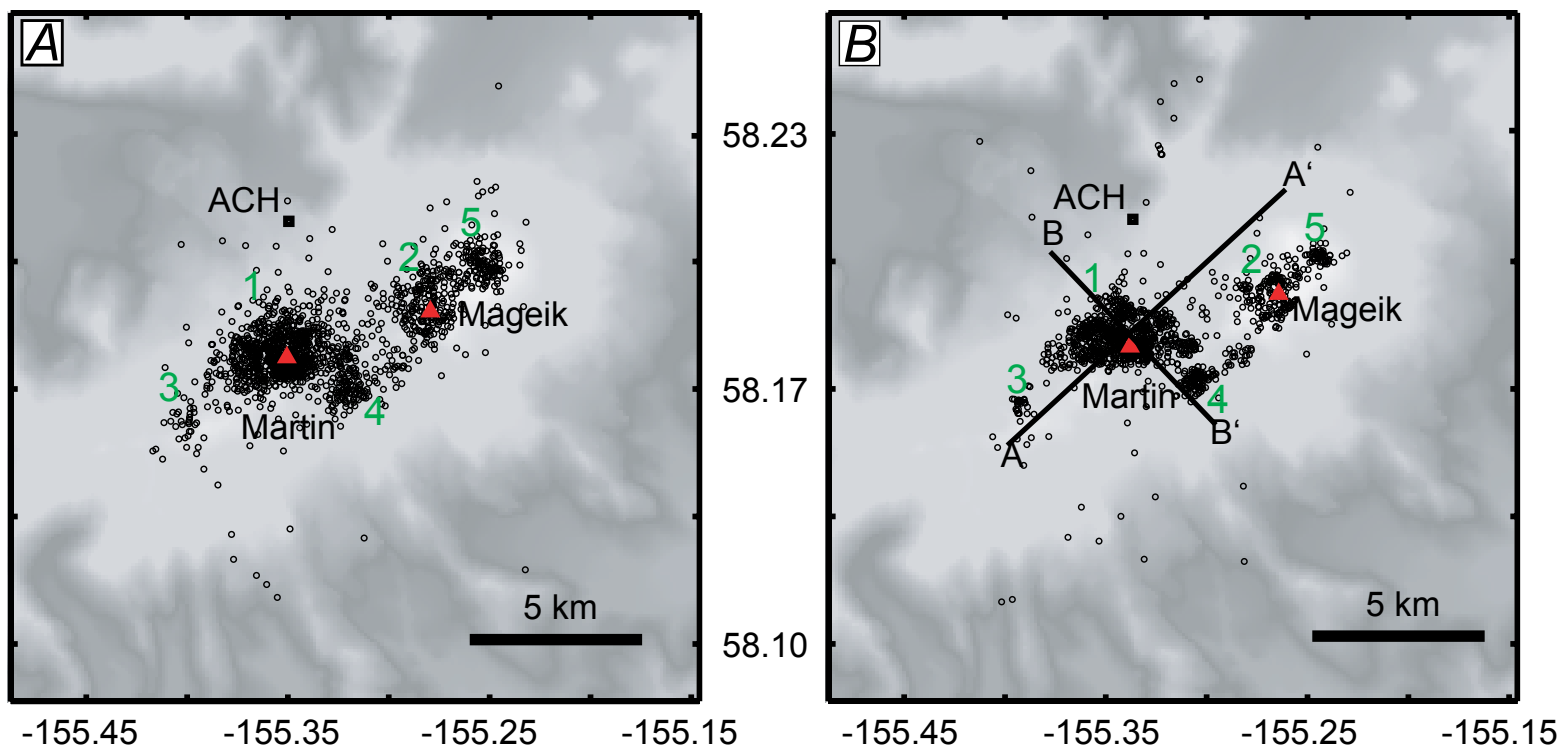

Figure 7. Earthquake epicenters near Mount Martin and Mount Mageik with $(A)$ Alaska Volcano Observatory catalog locations and $(B)$ relocated using HYPODD (Waldhauser, 2001) for March 2002-December 2005. The numbers refer to the five identified clusters of seismicity. The largest cluster is under Mount Martin (1), and the next largest cluster under Mount Mageik (2). The three smaller clusters are $4 \mathrm{~km}$ southwest of Mount Martin (3), $4 \mathrm{~km}$ southeast of Mount Martin (4), and $2 \mathrm{~km}$ northeast on Mount Mageik (5).
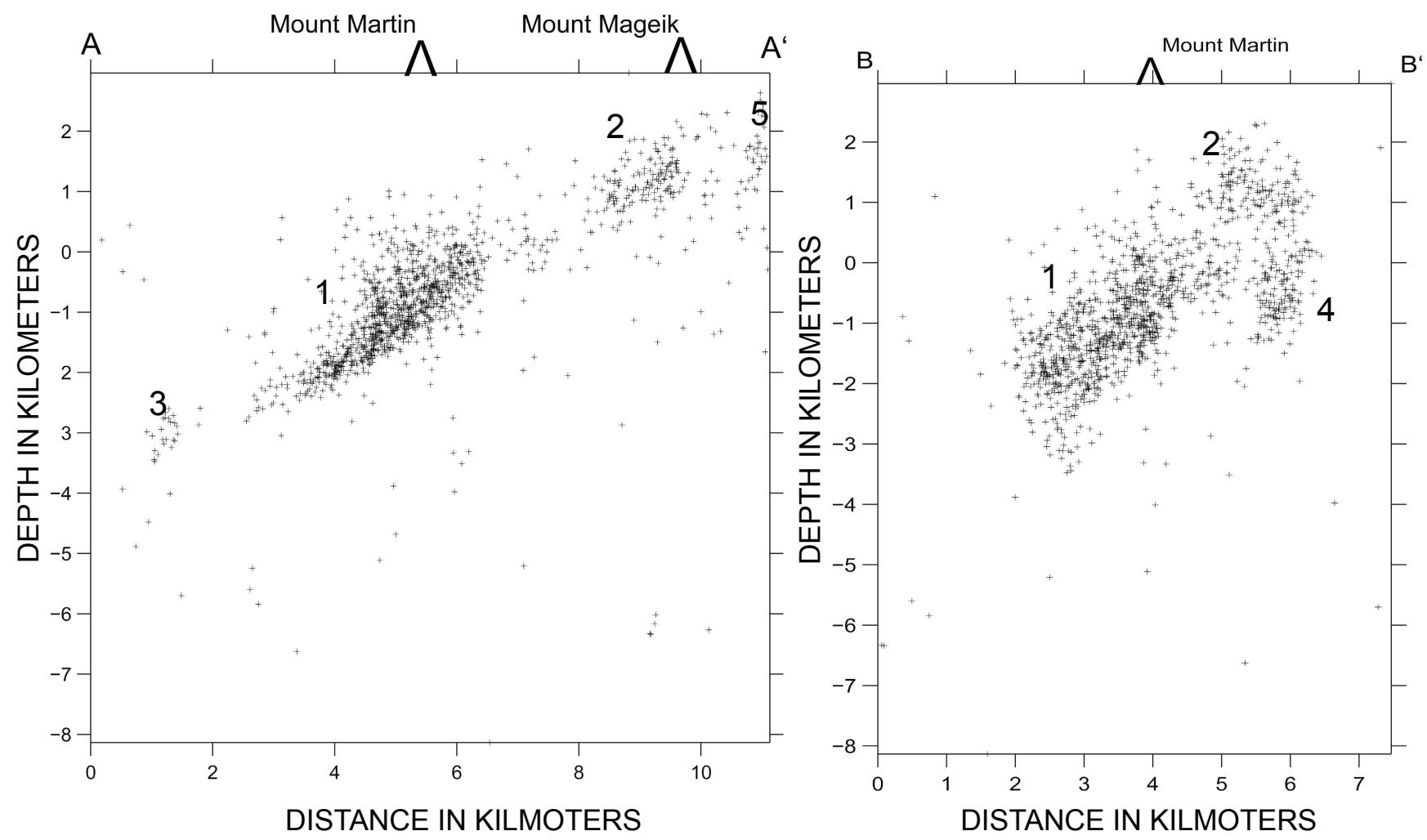

Figure 8. Cross section of earthquake hypocenters in the Katmai volcanic cluster from March 2002-December 2005, relocated using the double-difference technique shown in figure 7B. The locations of Mount Martin and Mount Mageik are shown for reference. 


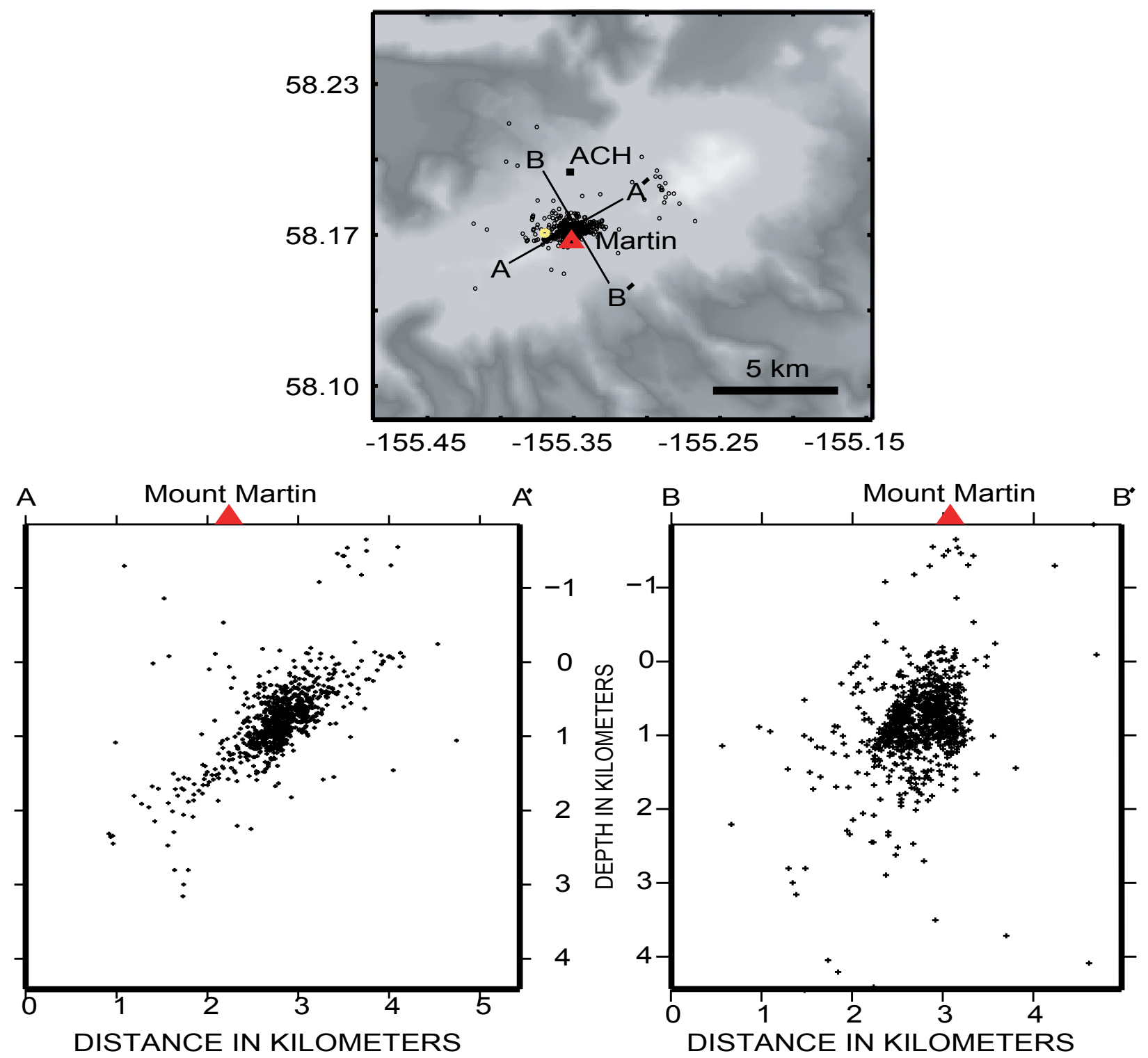

Figure 9. Map and cross sections showing the January 2006 Mount Martin earthquake swarm relocated using the double-difference technique. In the map view, open circles show hypocenter locations. Permanent seismograph stations are shown by open squares and labeled by station code. The $M_{\mathrm{L}}=2.1$ earthquake at 0652 UTC, January 11 , is shown by a yellow, open circle. In the cross sections, hypocenters are shown by plus symbols (+). Mount Martin is shown for reference (red solid triangle). 

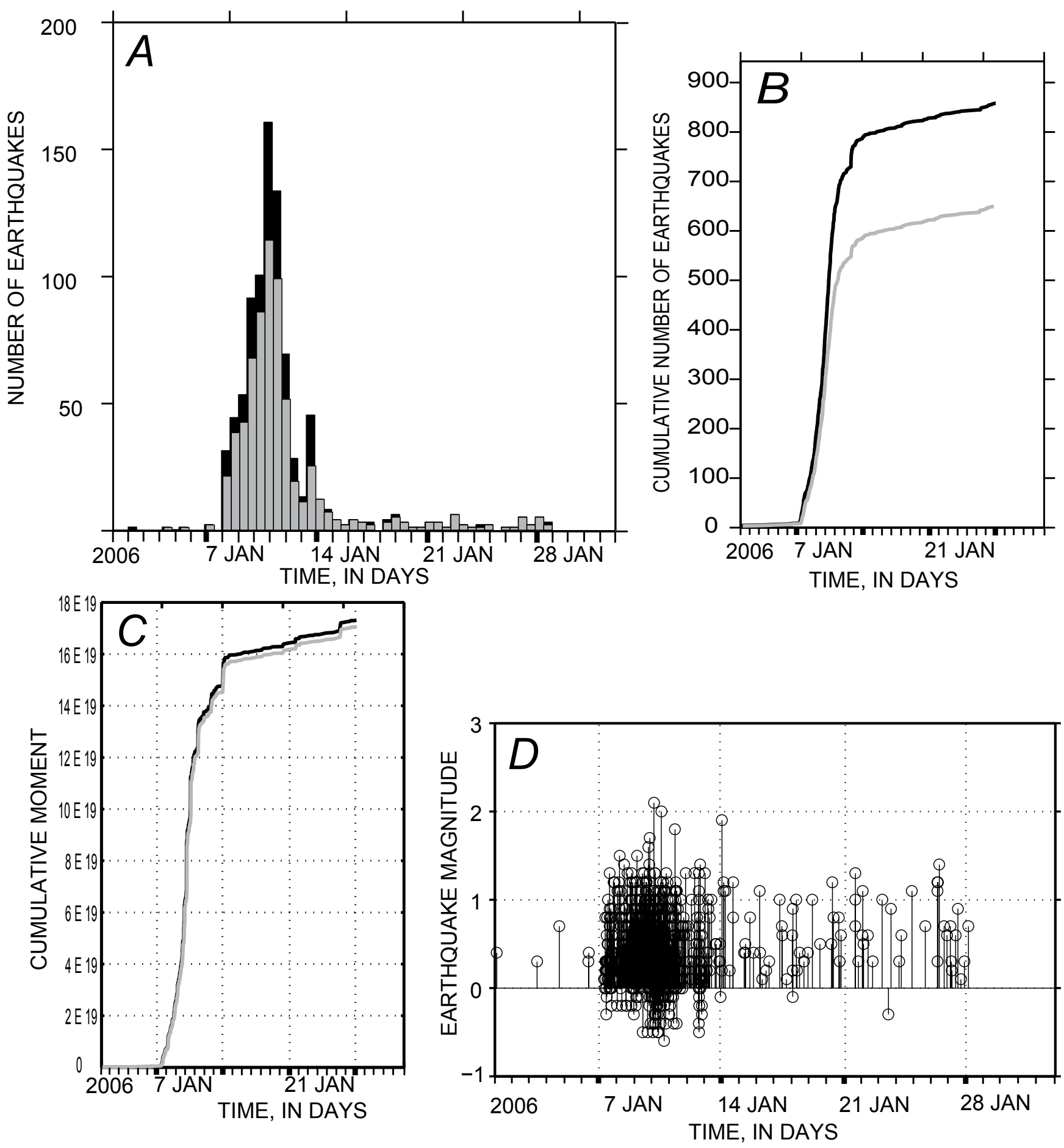

Figure 10. Summary plots of earthquake hypocenters of the January 2008 Mount Martin earthquake swarm. $A$, The number of located earthquakes (shown in black) per day in January 2006. Superimposed in grey are the number of earthquakes with the event magnitude at or above the magnitude of completeness $\left(M_{\mathrm{c}}=0.2\right)$. $B$, The cumulative number of earthquakes with time. The black curve includes all located earthquakes; the grey curve shows those earthquakes with a magnitude at or above the $M_{\mathrm{c}}$. $C$, The cumulative moment of Mount Martin earthquakes with time. The black curve includes all located earthquakes, the grey curve shows those earthquakes with a magnitude at or above the $M_{\mathrm{c}}$. $D$, Earthquake magnitude with time of all earthquakes associated with the Mount Martin swarm. 


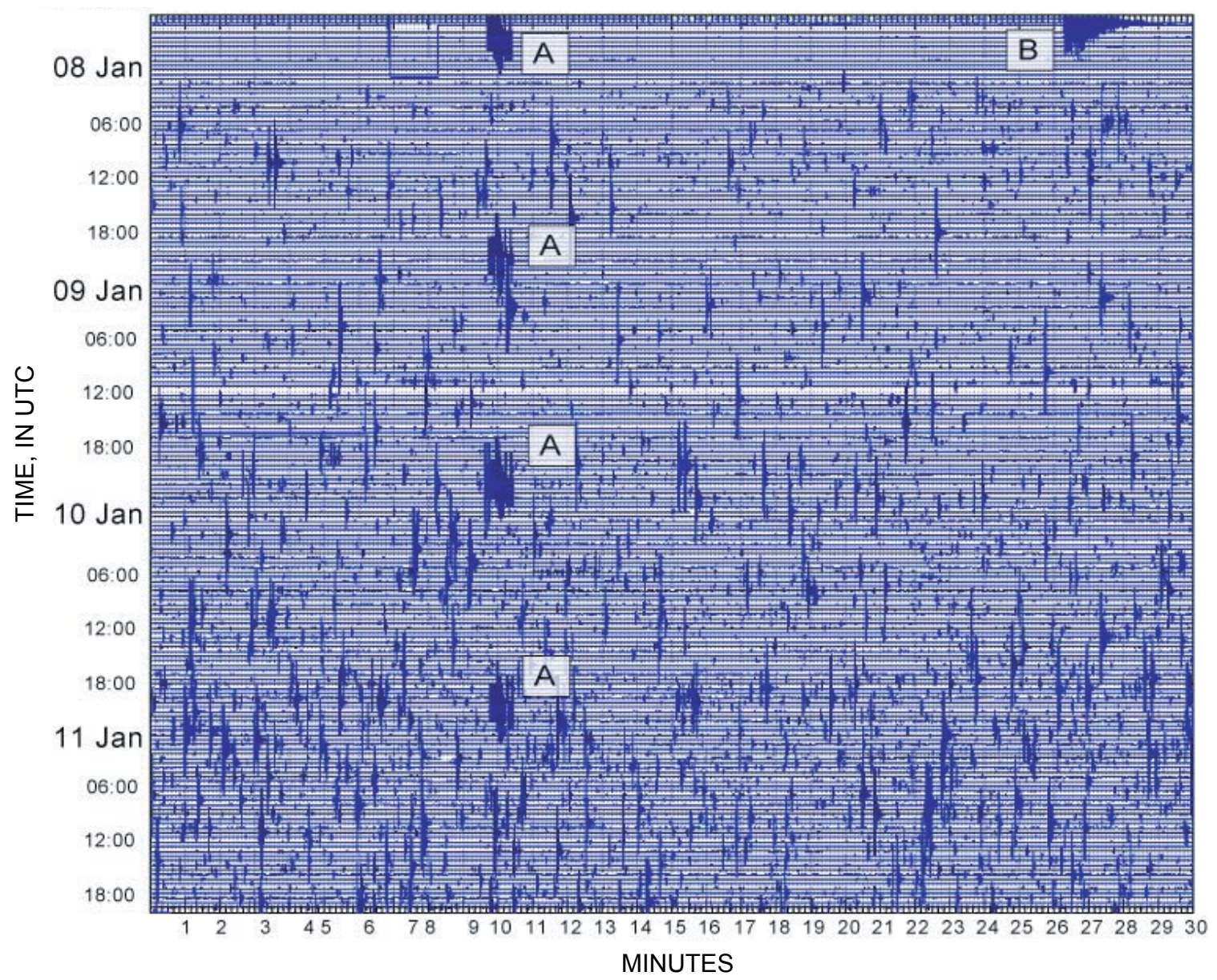

Figure 11. A 4-day velocity seismic record from 1800 UTC, January 7, 2006, through 1800 UTC, January 11, 2006, that shows the onset of the Mount Martin swarm as recorded on station ACH (fig. 2). Calibration pulses (marked by A) occur every 24 hours. The large earthquake labeled $B$, is a $M_{\mathrm{L}}=5.1$ earthquake $250 \mathrm{~km}$ southwest of Mount Martin. 


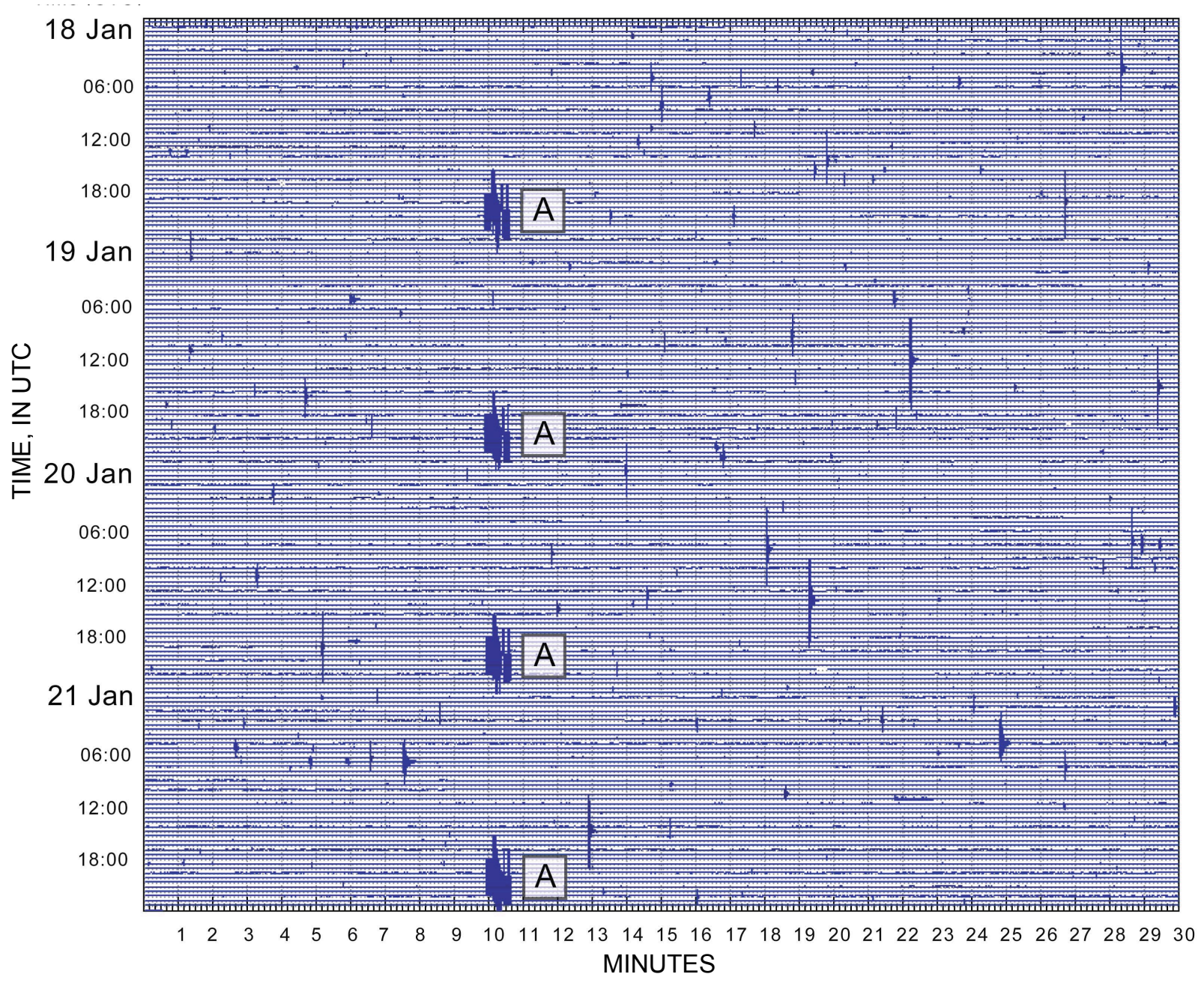

Figure 12. A 4-day velocity seismic record from 2200 UTC, January 12, 2006, through 2200 UTC, January 16, 2006, that shows the short-term increase in activity on January 14 for the Mount Martin swarm as recorded on station ACH (fig. 2). Calibration pulses (marked by A) occur every 24 hours. 
ary 2006 Mount Martin swarm occurred within the same space as the earthquakes that were located between 1996 and 2005 at Mount Martin (fig. 8). The robustness of HYPODD for the Mount Martin swarm was investigated by varying input parameters, such as station distribution (stations within 50 or $200 \mathrm{~km}$ of the earthquake cluster), quality of phase picks (all picks or those only of the highest quality), and the use of S-wave phases (with or without S-wave phases arrivals). No significant changes were seen in the output of HYPODD when these input parameters were varied (fig. 14).

The frequency-magnitude relationship or $b$-value (Ishimoto and Iida, 1939, Gutenberg and Richter, 1944) for the earthquakes before, after, and during the Mount Martin swarm were calculated by using the maximum likelihood method (Bender, 1983). The resulting $b$-value for the Mount
Martin swarm was $0.98 \pm 0.03$ (fig. 15). The $b$-values for Mount Martin earthquakes (earthquakes within $5 \mathrm{~km}$ of Mount Martin and closer to Mount Martin than Mount Mageik), before and after the Mount Martin swarm were $1.05 \pm 0.03$ (March 2002-December 2005) and 0.93 \pm 0.03 (February 2006-November 2007).

Focal mechanisms were calculated for 19 earthquakes by using FPFIT (Reasenberg and Oppenheimer, 1985) in the Mount Martin swarm that had a minimum of ten clear first motions. For the focal mechanisms within $1 \mathrm{~km}$ of Mount Martin, there was a mix of normal, thrust, and strike-slip focal-mechanism solutions, with normal focal mechanisms dominating (fig. 18). For the earthquakes with epicenters more than $1 \mathrm{~km}$ from Mount Martin, all focal mechanisms show normal faulting (fig. 17).

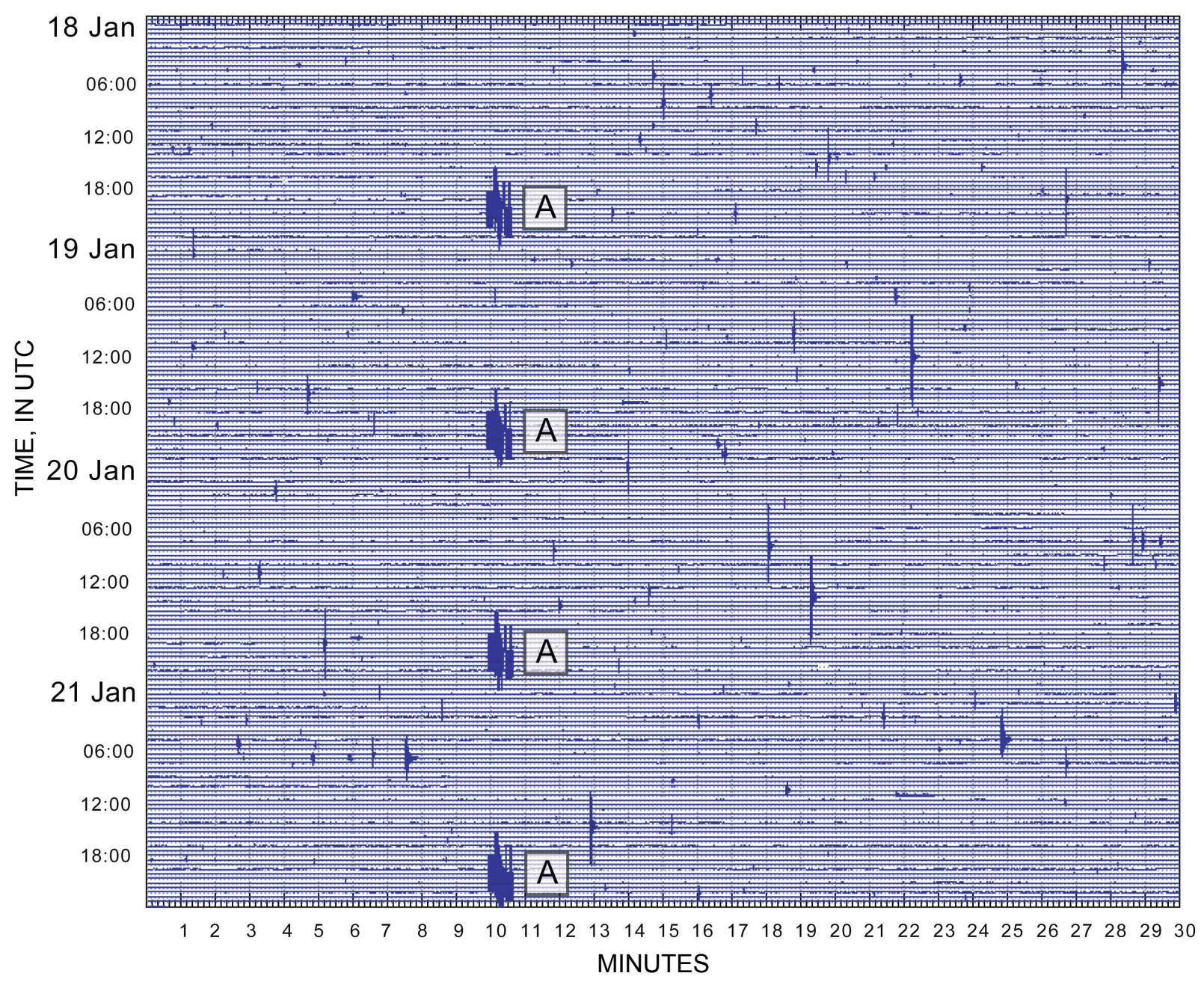

Figure 13. A 4-day velocity seismic record from 0000 UTC, January 18, 2006, through 2400 UTC January 21, 2006, that shows the seismicity at the end of the Mount Martin swarm as recorded on station ACH (fig. 2). Calibration pulses (marked by A) occur every 24 hours. 

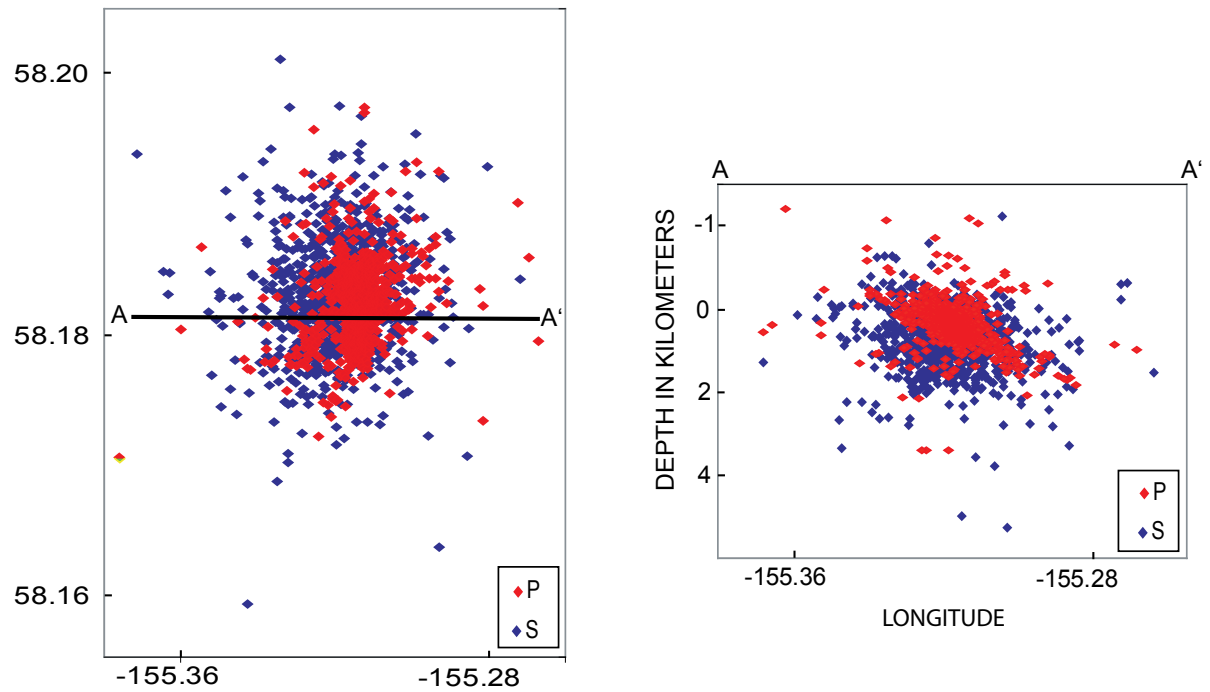

Figure 14. An example of the robustness of the Mount Martin earthquake data. The computer program HYPODD (Waldhauser, 2001) was used to relocate earthquakes by using only P-wave arrivals (relocated earthquakes in red) and only S-wave arrivals (relocated earthquakes in blue). The two clusters are similar to each other. The root mean square residual for the P-wave run is approximately half of that for the S-wave only run.

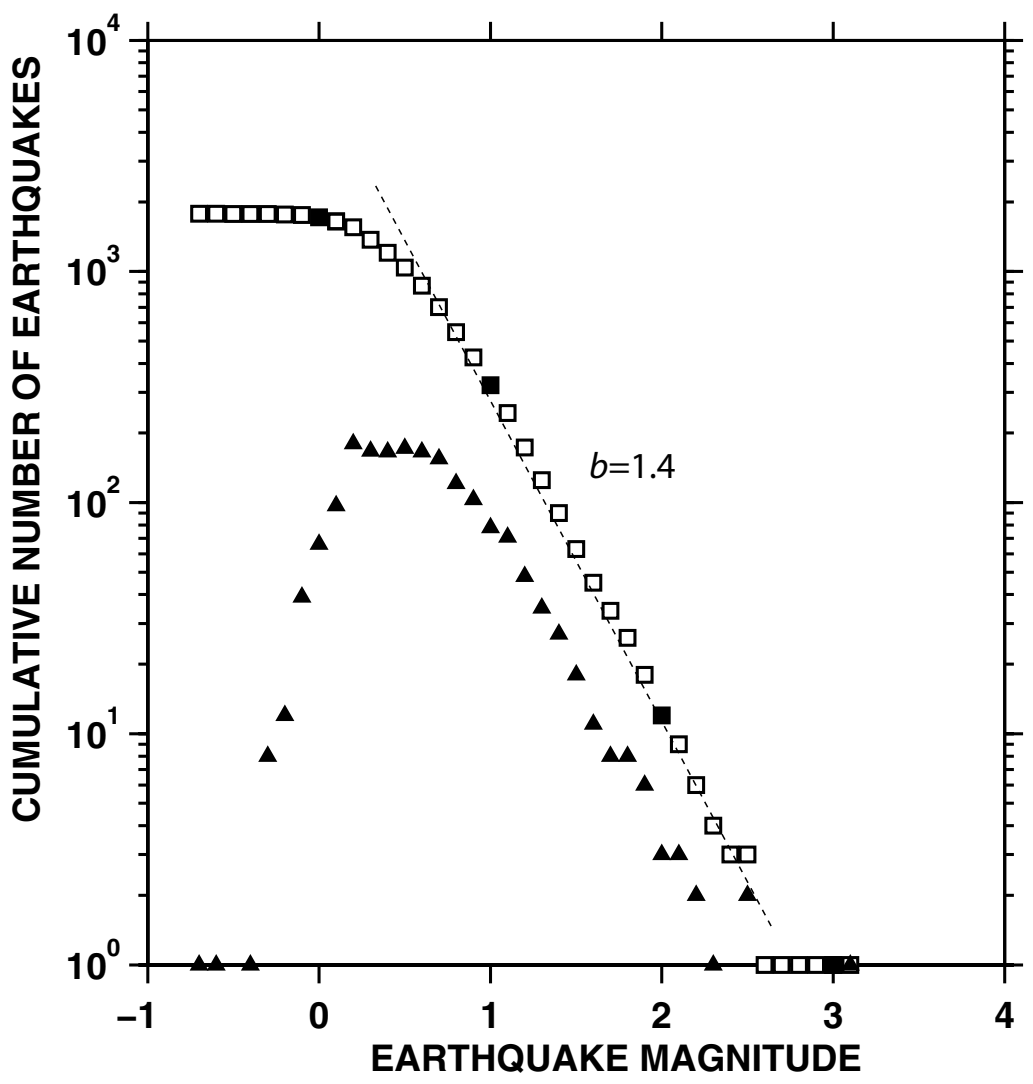

Figure 15. The frequency-magnitude distribution ( $b$-value diagram) for the January 2006 Mount Martin earthquake swarm. Squares are the cumulative number of earthquakes with magnitude $M$ and greater. Triangles show the number of earthquakes in each magnitude bin. The $b$-value, calculated using the maximumlikelihood method, is $0.98 \pm 0.03$ and is the slope of the line fit to the cumulative number of earthquakes. 


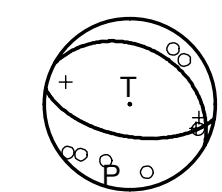

200601101554
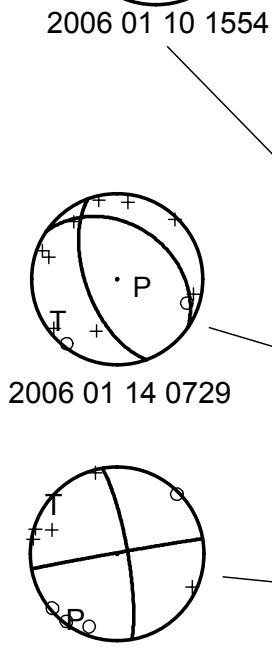

200601082145
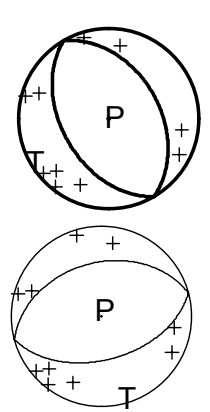

200601101826

年
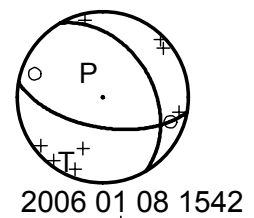

200601

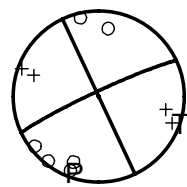

200601112240
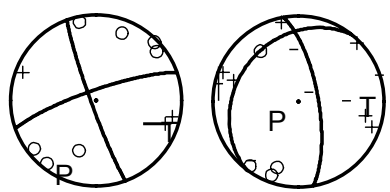

200601121837200601152238

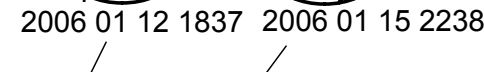

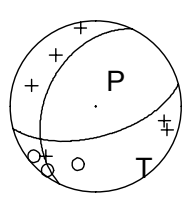

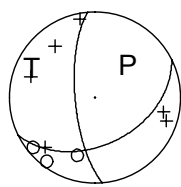

200601222205
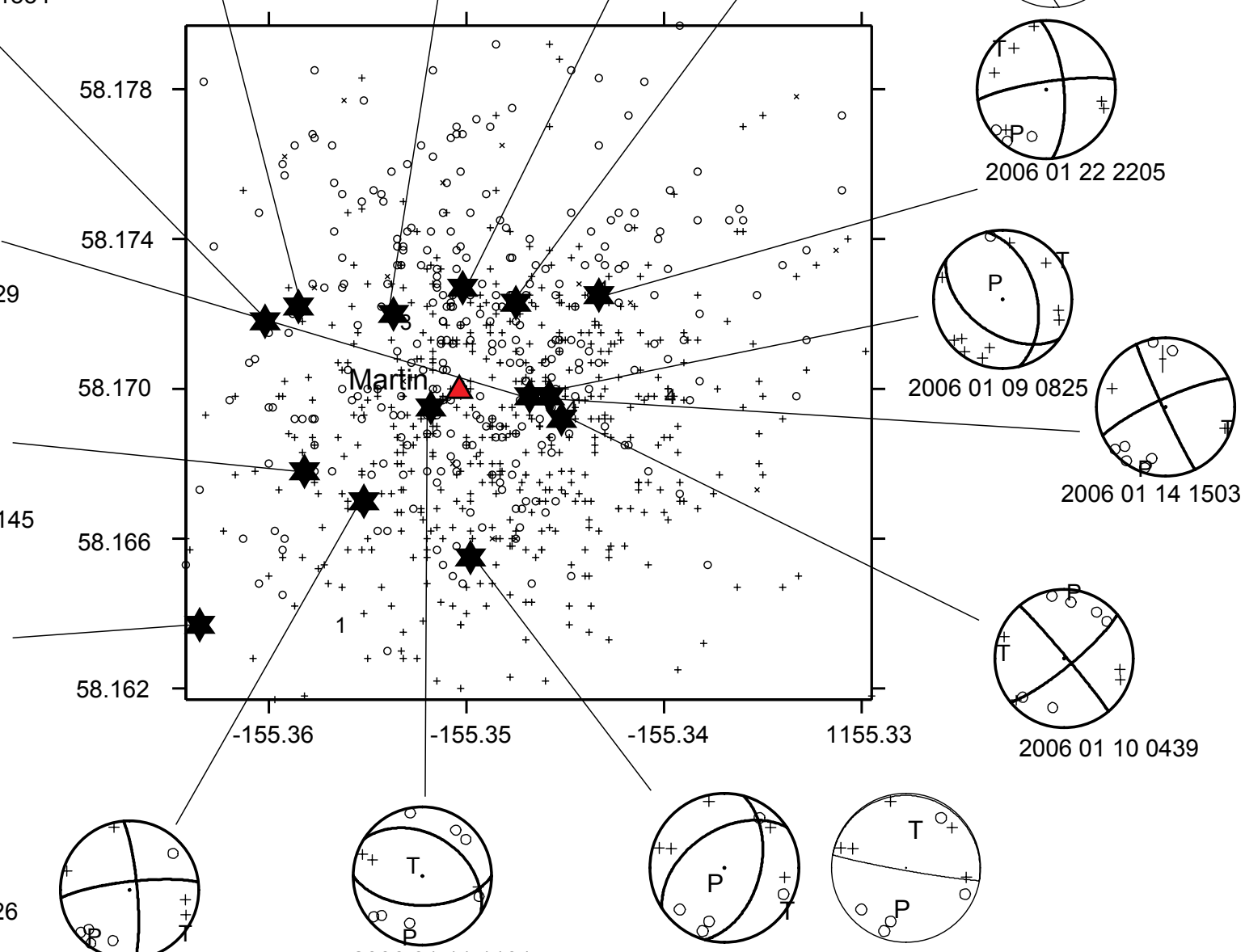

200601111101

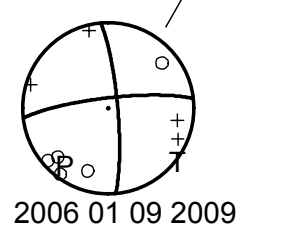

200601091330

Figure 16. Focal mechanisms for the Mount Martin earthquake swarm within the main cluster. Focal mechanisms are labeled with the date and time of event in the form YYYY MM DD HHMM (year, month, day, hour and minutes UTC). Where multiple solutions were possible, all focal mechanisms are shown. Preferred solutions, based on the best STDR (station distribution ratio), are shown in bold. Mount Martin is shown by a red triangle. 


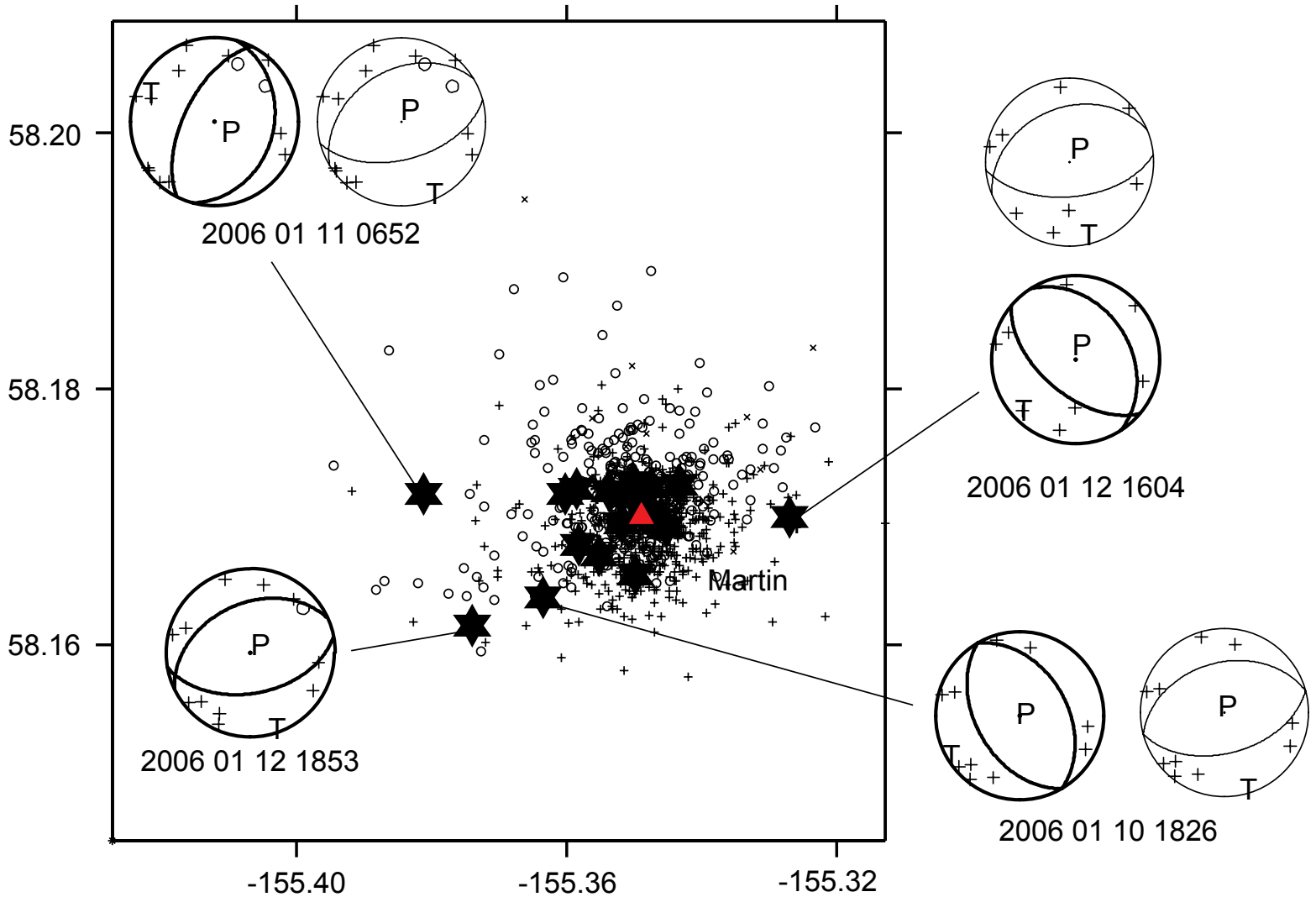

Figure 17. Focal mechanisms for the Mount Martin earthquake swarm outside the main cluster. Focal mechanisms are labeled with the date and time of event in the form YYYY MM DD HHMM (year, month, day, hour and minutes UTC). Where multiple solutions were possible, all focal mechanisms are shown. Preferred solutions, based on the best STDR (station distribution ratio), are shown in bold. Mount Martin is shown by a red triangle. 


\section{Discussion and Conclusions}

Since 1996, there have been four periods when there was a substantial increase in the number of located earthquakes at Mount Martin (fig. 4). The number of earthquakes (860) located in January 2006 was substantially higher than the next highest monthly total (120 located earthquakes in MayJune 2007) since AVO began to operate a network in the KVC. For each of these four periods of increased seismicity, the activity was characterized by an increasing number of earthquakes at the beginning of the swarm, a similar decay with temporary increases in activity, and the absence of a mainshock (figs. 5 and 10). This pattern is consistent with the characteristics of a typical volcanicearthquake sequence, as opposed to a tectonic-earthquake sequence that usually has a relatively large mainshock at the beginning of the sequence, with the number of earthquakes decaying with time. Further evidence of a volcanic cause is the absence of a well-defined fault plane defined by swarm hypocenters relocated with HYPODD and the position of the relocated earthquakes within the same volume where earthquakes occurred beneath the volcano edifice before January 2006.

The pattern of focal mechanisms for earthquakes in the 2006 Mount Martin swarm, with earthquake focal mechanisms close to Mount Martin showing a mix of normal, thrust, and strike-slip solutions and normal faulting dominating those focal mechanisms for earthquakes away from Mount Martin, is identical to the pattern seen for earthquakes that occurred in the area between 1995 and 2001 (Moran, 2003). Moran (2003) suggested that earthquakes beneath the volcanic centers were consistent with failure caused by edifice loading and that earthquakes away from the volcanoes were consistent with the regional stress related to the Aleutian megathrust.

Jolly and McNutt (1999) reported that the $b$-values for the southern end of the KVC, before and after the 1996 Mount Mageik earthquake swarm, were 0.92 (July 1995April 1996) and 0.98 (May 1997- December 1997). The $b$-value calculated by Jolly and McNutt (1999) for the Mount Mageik swarm and surrounding period was 1.54, and they suggested that the anomalous $b$-value of the 1996 Mageik earthquake swarm was related to an actively degassing intrusion. The anomalous $b$-values seen in the Mount Mageik swarm were not seen in the 2006 Mount Martin swarm. The absence of a significant change in $b$-values for the Mount Martin swarm suggests that the process that caused the 2006 Mount Martin swarm was fundamentally different than the process that initiated the 1996 Mount Mageik swarm.

The lack of any change in $b$-values before, during, or after the Mount Martin earthquake swarm, and the lack of a change in style of faulting, as indicated by focal mechanisms, suggest that the earthquakes during the swarm were responding to the same dominant stresses that existed before the January earthquake swarm. If there had been a significant intrusion of magma within the upper 4 to $5 \mathrm{~km}$ of the crust, the $b$-value for the Mount Martin swarm would be expected to increase similar to the $b$-value prior to the 1996 Mount Mageik swarms. Additionally, such an intrusion of magma should change the stress regime, resulting in a change in the style of faulting (Roman and Cashman, 2006), but the calculated focal mechanisms for the January 2006 earthquakes show no such change. We do not have sufficient data to further constrain the processes that were responsible for the generation of the 2006 Mount Martin Swarm. Monitoring of ground deformation and gas emissions could have provided a means to further resolve the processes that generate earthquakes beneath Mount Martin, but these methods were not available. The short duration of the swarm, the similarity in observed focal mechanisms to those for background periods, and the lack of additional signs of unrest, particularly the lack of long-period earthquakes, suggest that this swarm did not result from a large intrusion of magma into the shallow crust beneath Mount Martin.

\section{References}

Bender, B., 1983, Maximum likelihood estimation of $b$ values for magnitude grouped data: Bulletin of the Seismological Society of America, v. 73, p. 831-851.

Dixon, J.P., Stihler, S.D., Power, J.A., and Searcy, Cheryl, 2008, Catalog of earthquake hypocenters at Alaskan Volcanoes-January 1 through December 31, 2006: U.S. Geological Survey Data Series 326, 78 p.

Dixon, J. P., Power, J.A., Stihler, S.D., 2005, A comparison of seismic event detection with IASPEI and Earthworm Acquisition Systems at Alaskan volcanoes: Seismological Research Letters, v. 76, n. 2, p. 168-176.

Fierstein, J., and Hildreth, W., 2001, Preliminary volcanohazard assessment for the KVC, Alaska: U.S. Geological Survey Open-File Report OF 00-0489, 50 p., 1 plate, scale not applicable.

Gardner, C.A., and Guffanti, M.C., 2006, U.S. Geological Survey's Alert Notification System for Volcanic Activity: U.S. Geological Survey Fact Sheet, FS 2006-3139, 4 p.

Gutenberg, R. and Richter, C.F., 1944, Frequency of earthquakes in California: Bulletin of the Seismological Society of America, v. 34, p. 185-188.

Ishimoto, M., and Iida, K., 1939, Observations of earthquakes registered with the microseismograph constructed recently: Bulletin of the Earthquake Research Institute, University of Tokyo, v. 17, p. 443-478.

Johnson, C.E., Bittenbinder, A., Bogaert, B., Dietz, L., and Kohler, W., 1995, EARTHWORM-A flexible approach to seismic network processing: Incorporated Research Institutions for Seismology Newsletter, v. 14, no. 2, p 1-4.

Jolly, A.D., and McNutt, S.R., 1999, Seismicity at the volcanoes of Katmai National Park, Alaska-July 1995-December 1997: Journal of Volcanology and Geothermal Research, v. 93, n. 3, p. 173-190. 
Lahr, J.C., 1999, HYPOELLIPSE-A computer program for determining local earthquake hypocentral parameters, magnitude, and first motion pattern: U.S. Geological Survey Open-File Report 99-23, 116 p.

Lee, W.H.K., Tottinghamm, D.M., and Ellis, J.O., 1988, A PC-based seismic data acquisition and processing system: U.S. Geological Survey Open-File Report 88-751, 31 p.

Matumoto, T., 1971, Seismic body waves observed in the vicinity Mount Katmai, Alaska, and evidence for the existence of molten chambers: Geologic Society of America Bulletin, 82, p. 2905-2920.

Matumoto, T., and Ward, P.L., 1967, Microearthquake study of Mount Katmai and vicinity, Alaska: Journal of Geophysical Research, 72, p. 2557-2568.

Moran, S.C., 2003, Multiple seismogenic processes for high-frequency earthquakes at Katmai National Park, Alaska; evidence from stress tensor inversions of faultplane solutions: Bulletin of the Seismological Society of America, v. 93, p. 94-108.

Power, J.A., Stihler, S.D., White, R.A., and Moran, S.C., 2004, Observations of deep long-period (DLP) seismic events beneath Aleutian Arc volcanoes-1989-2002: Journal of Volcanology and Geothermal Research, v. 138, p. 243-266.

Pulpan, H., and Kienle, F., 1979, Western Gulf of Alaska seismic risk: Proceedings of the 11th Annual Offshore Technology Conference, Houston, Texas, p. 2209-2218. Reasenberg, P., and Oppenheimer, D., 1985, FPFIT, FFPLOT and FPPAGE - Fortran computer programs for calculating and displaying earthquake fault Plane solutions: U.S. Geological Survey Open-File Report OF 85-739, 25 p.

Riehle, J.R., Detterman, R.L., Yount, M.E., and Miller, J.W., 1987, Preliminary geologic map of the Mt. Katmai quadrangle and portions of the Feigned and Naknek quadrangles, Alaska: U.S. Geological Survey Open-File Report OF 87-0593, unpaged, 1 sheet, scale 1:250,000.

Roman, D.C. and Cashman, K.V., 2006, The origin of volcano-tectonic earthquake swarms: Geology, v. 34, p. 457-460.

Searcy, C.K., 2003, Station corrections for the Katmai Region Seismic Network: U.S. Geological Survey Open-File Report OF 03-0403, 14 p.

Waldhauser F., and Ellsworth, W.L., 2000, A doubledifference earthquake location algorithm-Method and application to the northern Hayward fault: Bulletin of the Seismological Society of America, v. 90, p. 1353-1368.

Waldhauser, F. (2001), HypoDD: A program to compute double-difference hypocenter locations, U.S. Geological Survey Open-File Report 01-113, 25p.

Ward, P.L., Pitt, A.M., and Endo, E., 1991, Seismic evidence for magma in the vicinity of Mt. Katmai, Alaska: Geophysical Research Letters, v. 18, p. 1537-1540.

Yang, Z.X., Waldhauser, F., Chen, Y.T., and Richards, P.G., 2005, Double-Difference relocation of earthquakes in central-western China, 1992-1999: Journal of Seismology, v. 9, p. 241-264. 

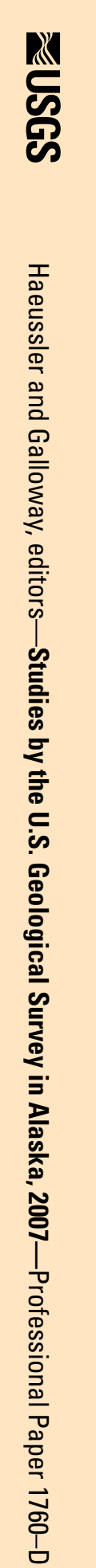